\title{
DETERMINANT OF FINANCIAL COMPANY PROFITABLITY
}

\author{
Suwinto Johan ${ }^{* 1}$ \\ *) Sekolah Tinggi Manajemen PPM \\ Jl. Menteng Raya No. 9-19, Jakarta 10340, Indonesia
}

\begin{abstract}
The purpose of the paper is to study the determinants of finance companies profitability. The finance company industry is one of main contributors of Indonesia economic growth during the last 15 years. Total asset of the industry is more than IDR 500 Trillion in 2018. The industry also considered as one the fastest growing industries during the last 15 year. We have analyzed the five main financial ratios and alliance impact as determinants of finance companies' profitability. The profitability is measured by profit size, return on asset and return on equity. The financial ratios are firm size, efficiency ratio, leverage ratio, asset allocation ratio, and profitability ratio. We use data panel. The empirical results show that the determinants of finance companies' profitability are leverage ratio, firm size, and efficiency ratio. However, the determinants of return on asset are net profit margin and efficiency ratio. On the contrary, the determinants of return on equity are firm size and equity size. Firm size has negative influence on return on equity. All determinants are significant at less than $1 \%$, only efficiency ratio on profitability has significant at less than $10 \%$.
\end{abstract}

Keywords: financial ratio, financial institution, profitability, return on assets, return on equity

Abstrak: Tujuan penelitian ini adalah mempelajari hal-hal yang memiliki dampak pada profitablitas perusahaan pembiayaan. Perusahaan pembiayaan merupakan salah satu kontributor pada pertumbuhan ekonomi Indonesia selama 15 tahun terakhir. Total aset daripada industri ini telah mencapai lebih dari IDR 500 trilliun di tahun 2018. Industri ini merupakan salah satu industri yang bertumbuh sangat pesat sejak 2001. Kami mempergunakan 5 rasio keuangan utama dan 1 rasio aliansi sebagai variabel yang memiliki dampak pada profitablitas. Variabel profitablitas adalah pendapatan bersih setelah pajak atau net income, return on asset dan return on equity. Rasio keuangan adalah total aset, rasio biaya pendapatan (rasio efisiensi), rasio leverage, rasio alokasi aset, dan aliansi. Penelitian ini mempergunakan panel data. Hasil penelitian menemukan bahwa rasio keuangan yang menentukan profitablitas adalah leverage ratio, ukuran perusahaan, dan rasio efisiensi. Sedangkan hal-hal yang memiliki dampak pada return on asset adalah net profit margin dan rasio efisiensi. Di lain pihak, determinan return on equity adalah ukuran perusahaan dan besaran modal sendiri. Ukuran perusahaan memiliki pengaruh negatif pada return on equity. Semua variabel memiliki nilai signifikan pada kurang dari 1\%, hanya rasio efisiensi yang memiliki signifikan pada kurang dari $10 \%$.

Kata kunci: financial ratio, financial institution, profitability, return on assets, return on equity

\footnotetext{
${ }^{1}$ Corresponding author:

Email: suwintojohan@gmail.com
} 


\section{INTRODUCTION}

All companies have purpose to increase the company value. The increasing value reflects on company business model. A good business model is showed by the ability to compete in the market which will be reflected in the profitability of the company.

Company value is the accumulation of profitability and value created from year to year. This profitability is the result of the company's management work from the beginning of establishment to the time of evaluation. Some management would like to know how to improve the profitability and the factors affecting the profitability of the company.

All functions in the company have contribution to the improvement of company value. One of them is financial management which can be the spearhead in increasing the value of company. The purpose of the company's management is to increase the shareholder's value. This increasing value of shareholders is known as the three main tasks of financial manager, which include assets allocation policy, determining funding source policy and dividend policy.

According to Maryadi \& Basuki (2014) who have analyzed the impact of banking management (liquidity, credit distribution, asset quality, operational efficiency rate) to return on asset of rural bank in Indonesia, the research shows that liquidity rate and credit distribution rate are not significant to ROA. Asset quality and efficiency ratiio have significantly negative influence to return on assets. CAR (Capital Adequacy Ratio) has positive and significant to return on assets.

The financial industry is one of the most dynamic industries. The financial industry consists of banks and non-bank financial companies. Non-bank financial companies include finance company, general insurance, life insurance, venture capital, securities, and others. This research will be focused on non-bank finance companies that are consumer finance companies.

The finance company industry is the third largest contributors of financial assets in Indonesia after banking and insurance. The total assets of the finance industry range from more than Rp500 trillion. Ten major players in the finance industry have alliance with the ten largest banks in Indonesia. The finance industry is growing rapidly in Indonesia with a CAGR of $120 \%$ over the past 15 years. The industry has more than 200 companies.

The finance industry is also a growth contributor in several other major industries such as automotive industry, mining industry, manufacturing industry, service industry, and others. The finance industry supports loans for car, motorcycles, heavy equipment, machinery, freight forwarder and others.

Thisstudy becomesuniqueby examining the determinant of financial institution profitability by using 3 proxies which are returning on equity, return on asset, and net profit. The company's goal is to maximize the value of the company. One of the variables in maximizing the value of a company is to obtain profits in accordance with the expectations of shareholders.

To meet the expectations of shareholders, the measurements of shareholder expectations are return on equity and return on assets. Determinants of Return on Assets (Lipunga, 2014) and Return on Equity (Zaid et al. 2014) use the profits (Samad, 2015) obtained divided by equity and assets.

Research on the financial institution profitability is still uncommon, especially in developing countries like Indonesia. Among some examples are Chronopoulos et al. (2013), Al-Jafari \& Alchami (2014), Tan \& Floros (2014), Capraru and Ihnatov (2014), Cekrezi (2015), Mwangi \& Murigu (2015), Samad (2015), Marnilin \& Darmansyah (2015), Ahmad (2015), and Utami \& Kusuma (2017).

\section{Profitability}

Chronopoulos et al. (2013) examined the determinants of profitability for a large sample of US banks over the period 1984-2010. The findings suggested that the competitive process reduces positions of abnormal profitability. There is also evidence that changes in regulation enacted during the 1990s affected both the level and persistence of bank profitability.

Al-Jafari \& Alchami (2014) investigated the determinants of bank profitability in the Syrian banking sector. The empirical results reveal that profitability persists to a moderate extent. All bank-specific determinants (liquidity risk, credit risk, bank size, and management efficiency) with the exception of bank capital, affect bank profitability significantly. 
Lipunga (2014) evaluated the determinants of profitability of listed commercial banks in developing countries specifically focusing on Malawi during the period 2009-2012 using internal-based and external (market)-based profitability measurements. The results of the regression analysis suggest that bank size, liquidity, and management efficiency have statistically significant impacts on ROA however capital adequacy has insignificant effect. On the other hand, results suggest that earnings yield is significantly influenced by bank size, capital adequacy, and management efficiency; whereas liquidity is found to have insignificant influence on earnings yield.

Dawood (2014) evaluated the profitability of the 23 commercial banks operating in Pakistan for the period of 2009 to 2012. The empirical findings of the research were that cost efficiency, liquidity and capital adequacy are those variables in the check of management that decide the profitability of commercial banks operating in Pakistan. Holding geographical and operating contracts have important implications for hotel profitability. Hotel size, level of indebtedness, exposure to crisis events, and levels of managers' educations are also influential (Aissa \& Goaied, 2015).

Tan \& Floros (2014) investigated the inter-temporal relationship between banking profitability, competition, and risk of a sample of Chinese commercial banks by employing several profitability and risk indicators and using Seemingly Unrelated Regression (SUR) under a panel data framework over 2003-2009. The results supported the Structure-Conduct-Performance (SCP) theory which states that there is a negative impact of competition on bank profitability. The research also found that banks with higher profitability normally operate in a less competitive environment.

Zaid et al. (2014) examined the determinants public based constructions companies' profitability in Malaysia from 2000-2012. This study used the return on equity (ROE) to measure profitability of company, debtequity ratio to measure capital structure, quick ratio to measure liquidity, sales used to measure the size of company and term premium to measure the economic cycle. The result showed that the liquidity and size have significant relationship with profitability. The negatively insignificant relationship is found between capital structures with profitability.
Capraru and Ihnatov (2014) assess the main determinants of banks' profitability in five selected CEE countries over the period 2004-2011. The sample contains 143 commercial banks. The result showed that efficiency and capital adequacy growth influence the bank profitability. The higher the capital adequacies, the more profitable the banks are.

Dietrich and Wanzenried (2014) analyzed how bankspecific characteristics, macroeconomic variables, and industry-specific factors are affecting the profitability of 10.165 commercial banks across 118 countries over the period 1998-2012. The level of income has an important impact on the determinants of bank profitability.

Béjaoui \& Bouzgarrou (2014) studied the persistence of profit and the effect of bank-specific determinants of Tunisian bank profitability. The results found a positive relationship between capital and profitability. The liquidity risk management by Tunisian banks shows that the overuses of deposits to finance loans are likely to weigh on the profitability of the banks. The results showed that credit risk management is negatively related to bank profitability and that deposit and development banks suffer from the bad quality of their loans and the lack of provisions over the period 1999-2010.

Samad (2015) examined the impact of bank specific characteristic and macro variables in determining the banks' profitability of Bangladesh banking industry. The results indicated that loan deposit, loan loss provision, equity to total asset, and operating expense to total assets are significant factors.

\section{Leverage}

Tariq etal. (2014) examined the influence of determinants on the performance of commercial banks in Pakistan. They found that the capital strength of a bank is utmost significance in affecting its performance, as well as a well-capitalized bank. The asset quality also affects the bank's performance positively.

Mwangi \& Murigu (2015) stated that profitability positively related to leverage, equity capital, management competence index, and negatively related to size and ownership structure. The research did not find any relationship between performance and retention ratio, liquidity, underwriting risk, and age. The study recommended that the bank's performance positively increase leverage, equity capital, and quality of staff. 
Cekrezi (2015) explored the factors that affect financial performance of Albanian insurance companies. The results showed that leverage and risk have negative impacts and tangibility has positive impact on the return on asset of these companies.

\section{Efficiency (Cost To Income)}

Capraru and Ihnatov (2015) found that cost to income ratio, credit risk, and market concentration had a negative influence on bank's profitability, and bank liquidity only for ROAE and NIM. The research used return on average assets, return on average equity, and net interest margin as the proxy for banks profitability. The research suggested that better supervision for credit risk and liquidity and maintaining a competitive banking environment.

Petria et al. (2015) found that credit and liquidity risk, management efficiency, diversification of business, market concentration, and the economic growth have influences on bank profitability; both on return on asset and return on equity. Also, market concentration has a positive influence on bank profitability. Size is significant of positive relationship with profitability for selected listed manufacturing companies in Sri Langka. Leverage and liquidity indicate insignificant impacts on profitability (Pratheepan, 2014)

Ahmad (2015) analyzed determinants that affect State Development Bank's (BPD) profitability. The research found that bank efficiency, non-performing loan, and net interest margin have significant impacts on bank profitability.
Marnilin \& Darmansyah (2015) researched on the determinants analysis of earning persistence in the service companies on Indonesia stock exchange. The result showed that rate of debt is affecting significantly to earnings persistence. Cash flow, debt levels, and tax rate also have effects on earning persistence. The effect of IFRS adoption to earning quality depends on the level of investor protection in a country. The concentrated ownership structure increases the relationship between IFRS adoption and earning quality. (Utami \& Kusuma, 2017).

\section{Firm Size}

Burca \& Batrinca (2014) attempted to analyze the determinants of the financial performance in the Romanian insurance market during the period 20082012. The final results achieved by applying specific panel data techniques, the determinants of the financial performance in the Romanian insurance market are the financial leverage in insurance, company size, growth of gross written premiums, underwriting risk, risk retention ratio, and solvency margin.

Although there are already numerous researches concerning the determinants of financial institution profitability, especially banking industry, there is no conclusive result yet on consumer finance company industry. The previous research as stated in Table 1. Therefore, it is important to conduct a research on this topic, especially in a specific industry such as finance companies industry.

Table 1. Previous research

\begin{tabular}{lll}
\hline Variable & Researched By & Result to Profitability \\
\hline Profitability Ratio & Dietrich and Wanzenried (2014), Ahmad (2015) & + \\
Leverage & Dawood (2014), Al-Jafari \& Alchami (2014) & $+/-$ \\
& Lipunga (2014), Burca \& Batrinca (2014), Cekrezi (2015), Marnilin \& & \\
& Darmansyah (2015), Mwangi \& Murigu (2015), Samad (2015) & \\
Cost Income & Dawood (2014), Al-Jafari \& Alchami (2014) & + - \\
Ratio & Lipunga (2014), Capraru and Ihnatov (2014), Ahmad (2015), Samad (2015) & \\
Firm Size & Al-Jafari \& Alchami (2014), Lipunga (2014) & + - - \\
& Dawood (2014), Burca \& Batrinca (2014) & \\
\hline
\end{tabular}


This paper will study the determinant of profitability of consumer finance industry in Indonesia during 20012015. The performance measurement will be based on the financial performances. In this research, the research questions are following: Do profitability ratio, leverage ratio, efficiency ratio, firm size ratio, and asset allocation ratio have any influence on financial company's profitability?; Do profitability ratio, leverage ratio, efficiency ratio, firm size ratio, and asset allocation ratio have any influence on financial company's return on assets?; Do profitability ratio, leverage ratio, efficiency ratio, firm size ratio, and asset allocation ratio have any influence on financial company's return on equity?.

\section{METHODS}

This research used secondary data which was collected from various official publication by the institutions. The sample data are panel data which consisted of cross section and time series data from 2001-2015. The sample data is the finance company who issued their official financial statement during the research period. The sample consisted of 90 finance companies. All finance companies are registered under the Financial Service Authority (FSA) / Otoritas Jasa Keuangan. The formulation of the variables is described in Table 2.

The variables in this research refer to six key ratios on profitability ratio, liquidity ratio, asset efficiency ratio, firm size, equity size, asset composition, and the impact of related industry alliance. This study added a specific measurement on the impact of related industry alliance. The impact of related industry alliance is to measure the impact of parent holding company in determining the profitability. The panel data is showed below:

$$
\begin{aligned}
\mathrm{Y}_{\mathrm{it}}= & \underset{\mathrm{a}}{\mathrm{a}} \mathrm{b}_{1} \mathrm{Pro}_{\mathrm{it}}+\mathrm{b}_{2} \mathrm{Lev}_{\mathrm{it}}+\mathrm{b}_{3} \text { PATA }_{\mathrm{it}}+\mathrm{b}_{4} \mathrm{Eff}_{\mathrm{it}}+\mathrm{b}_{5} \mathrm{FSi}_{\mathrm{it}}+\mathrm{b}_{6} \mathrm{All}_{\mathrm{it}} \\
& +\varepsilon
\end{aligned}
$$

Description: Yit (Profitability Ratio / Return On Asset / Return On Equity); Pro (Net Interest Margin); Lev (Leverage Ratio); AR (Asset Ratio); Eff (Efficiency Ratio/Cost Income Ratio); FSi (Firm Size); All (Dummy of Alliance, 1 for related alliance and 0 for non-related alliance). Based on the previous research, the hypothesis is shown in Table 3.
Based the previous research, we make hypothesis that profitability ratio, leverage ratio, asset allocation ratio, efficiency ratio; firm size will have positive impact on the profitability of the financial institution as shown in Table 3. Alliance with related institution will also have a positive impact to the profitability of the firm.

The independent variables in this research refer to six key ratios on profitability ratio, liquidity ratio, asset efficiency ratio, firm size, equity size, asset composition, and the impact of related industry alliance. The dependent variable in this research is divided into 3 indicators which are profit of the firm, return on equity and return on assets as shown in Figure 1.

Shareholders expectations are measured by return on equity and return on assets of the investment. Therefore, in this research return on equity and return on assets are used are the variables. And, determinants of return on assets and return on equity is the profit obtained by the firm divided by equity and assets.

Table 2. Research Variable

\begin{tabular}{ll}
\hline Variables & Measurements \\
\hline Profit & Pro $=\ln ($ Net Income $)$ \\
Return On Asset & $\mathrm{ROA}=($ Net Income $) /($ Total Asset $)$ \\
Return On Equity & $\mathrm{ROE}=($ Net Income $) /($ Total Equity $)$ \\
Net Interest & $\mathrm{NIM}=($ Net Income $) /$ (Productive \\
Margin & $\mathrm{Asset})$ \\
Leverage & $\mathrm{LEV}=($ Total Debt $) /($ Total Equity $)$ \\
Asset Ratio & $\mathrm{AR}=($ Productive Asset $) /$ Total Asset $)$ \\
Effic Ratio & $\mathrm{Eff}=$ Expense $/$ Revenue \\
Firm Size & $\mathrm{FSi}=\ln ($ Total Asset $)$ \\
Alliance & $\mathrm{Alliance}=1 ;$ Non Alliance $=0$ \\
\hline
\end{tabular}

Table 3. Research Hypotheses

\begin{tabular}{clc}
\hline Hypothesis & Determinants & $\begin{array}{c}\text { Expected Relationship } \\
\text { to Profitability }\end{array}$ \\
\hline H1 & Net Profit Margin & Positive \\
H2 & Leverage & Positive \\
H3 & Asset Ratio & Positive \\
H4 & Cost Income Ratio & Positive \\
H5 & Firm Size & Positive \\
H6 & Alliance & Positive \\
\hline
\end{tabular}




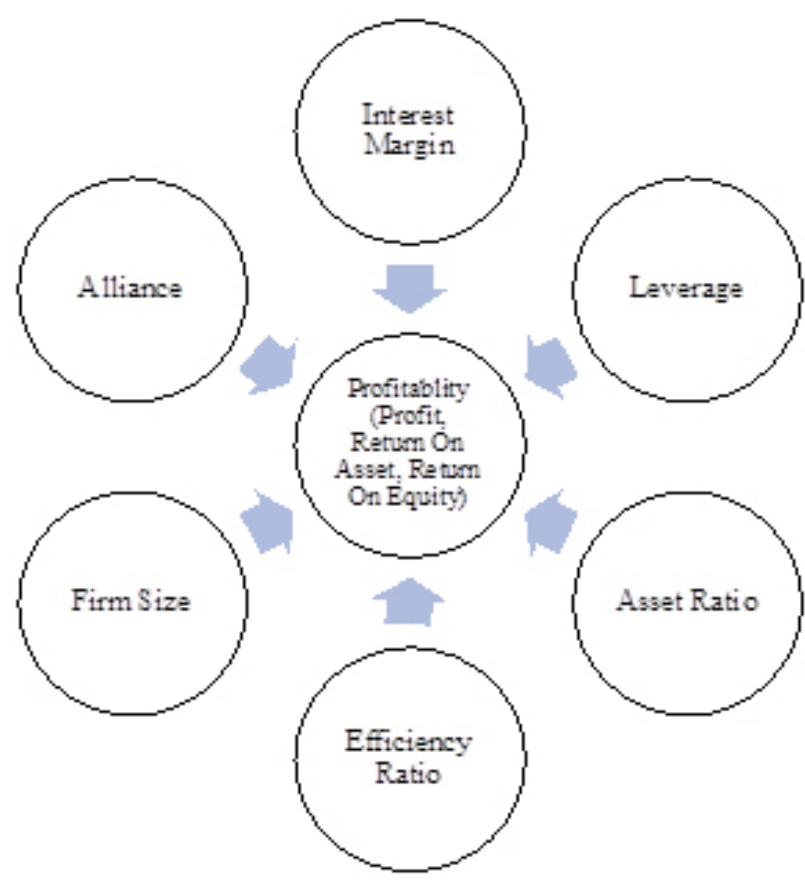

Figure 1. Research framework

\section{RESULTS}

\section{Descriptive Statistic}

The total research sample is 1350 which is consisted of 90 companies. The Net profit of finance companies from 2001-2016, there are some that had losses up to Rp13 billions and there are also some companies that gained profit up to Rp43 billion. With the average financing companies studied had profits about Rp23 billion.

The average ratio of debt to equity was $1.28 \mathrm{x}$, with the lowest having no debt and the largest having a large debt of $747 x$ of debt to equity ratio. For an average firm size, it had total assets of Rp33 billion. The average ratio of productive assets to total assets is $75 \%$, there are some finance companies that do not have productive assets. There are some other finance companies that have earning assets up to $913 \%$. There are one company in the research have zero asset, therefore the minimum of firm size is zero.

There are $47 \%$ of companies having alliances with the parent company in the value of the financing chain. The value of this chain is holding companies engaged in banking and also automotive industries. The details measurement is stated in Table 4.
Profitablity (Hypotheses 1)

From the test result with Fixed Effect Model as shown in Table 5, it was found that leverage ratio had significant influence in $<1 \%$ with positive influence. It can be concluded that the higher the leverage, the better the profitability. It happens because of the cheaper cost of debt compared to cost equity. Leverage values also have a maximum limit; otherwise, high leverage can lead to financial distress. This research supports the results of researches done by Marnilin \& Darmansyah (2015) and Capraru and Ihnatov (2014).

Firm Size shows the effect on the profitability of the finance company. Firm Size has a positive influence at significant level $<1 \%$ with Fixed Effect Model. The larger the size of the company, the higher the profitability is. The source of income derived from productive assets. Productive assets are part of the firm's size. It also supports that the larger the finance company, the greater the profit is. This research supports the researches done by Petria et al. (2015), Al-Jafari \& Alchami (2014), Lipunga (2014). Cost Income Ratio (efficiency ratio) shows the significance at $<10 \%$ level with positive influence. Efficiency ratio is a comparison of operating costs compared to operating income. It shows that the more efficient a company, the higher the profitability of the finance company is. The biggest cost to a finance company is the employee cost. This finding is in line with researches done by Capraru and Ihnatov (2014), A1-Jafari \& Alchami (2014), Lipunga (2014).

Based on the fixed effect model test, the Net Profit Margin variable does not show any significant effect on the profitability of the finance company. It may occur due to the condition of some companies that still have some losses. They are caused by the provision of bad debts or bad debts. Hence, the effect on profitability is not solely by net profit margin.

Asset Ratio is the ratio of earning assets to total assets. Asset Ratio based on fixed effect model; do not have a significant effect on the profitability of finance companies. Asset Ratio that is not significant indicate that the source of income is not merely a matter of earning assets but also other sources of income as well as other costs. 
Table 4. Descriptive Statistic

\begin{tabular}{lccccc}
\hline Equation & $\mathrm{N}$ & Minimum & Maximum & Median & Standard Deviation \\
\hline Net Profit Margin & 1,350 & -13928.57 & $43,533.33$ & 22.77 & $1,259.17$ \\
Leverage & 1,350 & 0.00 & 747.66 & 1.28 & 20.37 \\
Asset Ratio & 1,350 & 0.00 & 913.58 & 75.16 & 41.52 \\
Cost Income Ratio & 1,350 & -46.71 & $31,666.67$ & 152.70 & $1,070.12$ \\
Firm Size & 1,350 & 0.00 & $574,911,647.00$ & $33,304,637.56$ & $4,004,731.40$ \\
Alliance & 1,350 & 0.00 & 1.00 & 0.47 & 0.50 \\
\hline
\end{tabular}

Table 5. Research Results on Profitablity

\begin{tabular}{|c|c|c|c|}
\hline Equation & PLS & FEM & REM \\
\hline \multirow[t]{2}{*}{ Net Profit Margin } & 0.00003 & 0.00001 & 0.00001 \\
\hline & $(0.00001)$ & $(0.00001)$ & $(0.00001)$ \\
\hline \multirow[t]{2}{*}{ Leverage } & $0.01867 * * *$ & $0.01543 * * *$ & $0.01632 * * *$ \\
\hline & $(0.00341)$ & $(0.00312)$ & $(0.00310)$ \\
\hline \multirow[t]{2}{*}{ Asset Ratio } & -0.00256 & -0.00049 & -0.00094 \\
\hline & $(0.00172)$ & $(0.00162)$ & $(0.00160)$ \\
\hline \multirow[t]{2}{*}{ Cost Income Ratio } & 0.00001 & $0.00013 *$ & 0.00011 \\
\hline & $(0.00008)$ & $(0.00001)$ & $(0.00000)$ \\
\hline \multirow[t]{2}{*}{ Firm Size } & $1.85477 * * *$ & $1.64882 * * *$ & $1.71838 * * *$ \\
\hline & $(0.03420)$ & $(0.04258)$ & $(0.38880)$ \\
\hline \multirow[t]{2}{*}{ Alliance } & $0.31620 * *$ & 0.07689 & 0.37890 \\
\hline & $(0.14446)$ & $(0.44414)$ & $(0.24199)$ \\
\hline \multicolumn{4}{|l|}{ Note: } \\
\hline \multirow{2}{*}{\multicolumn{2}{|c|}{$\begin{array}{l}\text { 1) Estimation coefficient } \\
\text { 2) Numbers in ( ) states the estimated standard error } \\
\text { 3) *) Significant at } \alpha=10 \%\end{array}$}} & \multicolumn{2}{|r|}{ Model } \\
\hline & & & Haushman \\
\hline \multicolumn{2}{|c|}{$\begin{array}{l}\text { 3) *) Significant at } \alpha=10 \% \\
* * \text { Significant at } \alpha=5 \%\end{array}$} & Result & $\begin{array}{ll}0.0000 & 0.0037\end{array}$ \\
\hline \multicolumn{2}{|c|}{$* * *$ ) Significant at $\alpha=1 \%$} & Selected Model & Fixed Effect Model \\
\hline
\end{tabular}

Alliances with companies that support the finance companies do not have any significant effect on profitability. This is due to several parent companies transferring pricing policy to their financing subsidiaries. Where the excess value of the profits is transferred to the parent company in the form of fee based

Return on Asset (Hypotheses 2)

Based on tests of Chow, Haushman and LM, it is concluded to use the Random Effect Model, where the Hausman value $=0,4954$ and $L M=0.0002$ as shown in Table 6. With random effect model test with significant $<1 \%$, net profit margin has a significant influence on return on asset. Net profit margin is the ratio of total income to productive assets. Return on Asset is the ratio of profit to total asset. The bulk of assets are earning assets. The higher the net profit margin, the greater the profit. With the greater the profit, then the return on assets will be greater. This result is in line with researches done by Dietrich and Wanzenried (2014), and Ahmad (2015).

Based on random effect model test, the efficiency ratio has a significant effect on return on asset. the efficiency ratio is the ratio of operational cost to operational income. The lower the efficiency ratio, the more efficient a financial company is. Operational costs are the largest cost component of a finance company. Operational costs represent the employee costs. This research is in line with researches done by Petria et al. (2015), Al-Jafari \& Alchami (2014), Lipunga (2014).

The leverage test with random effect model has no significant effect. It could be happened due to the small ratio of finance companies. With low leverage, then leverage is not significant influence on return on assets. This study supports Pratheepan (2014) research. 
Table 6. Research Results on Return on Asset

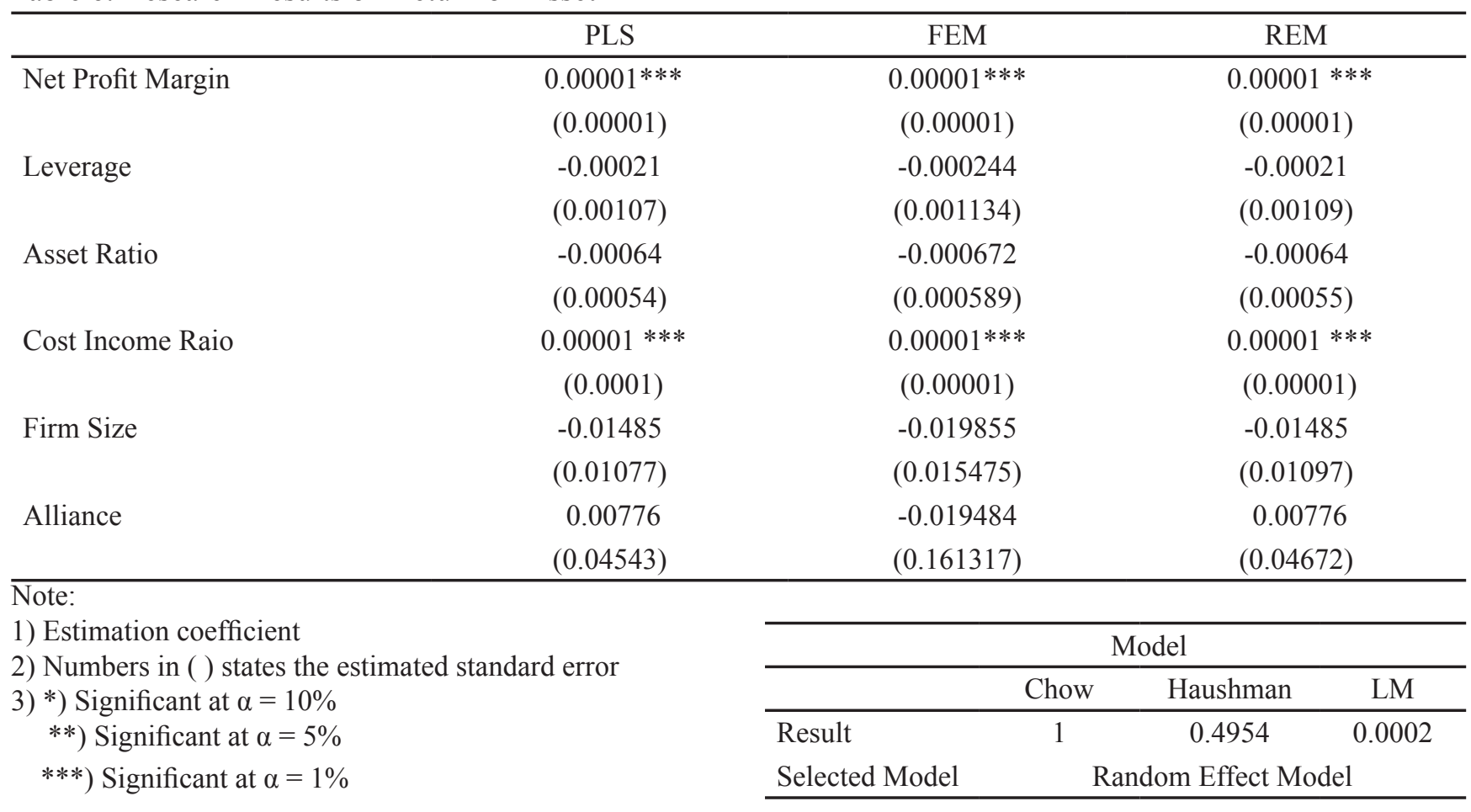

Asset ratio does not have any significant effect on return on assets. Asset Ratio is the ratio between earning asset ratio to total assets. Large Asset ratios will generate substantial revenue. Profitability depends on income from productive assets, after reduced by the costs. So, Asset Ratio is not a benchmark for return on assets.

Based on random effect model testing, Firm Size ratio has no positive effect on the return on equity ratio. Return on equity is the ratio between net incomes to total equity. These results indicate that firm size is not a major factor in determining profitability; as well as efficient factors.

Alliances with companies that have direct support have no significant effect on finance companies. It suggests that finance companies need to maintain their own efficiency level rather than dependence on the parent company.

\section{Return On Equity (Hypotheses 3)}

Based on testing of Chow as shown in Table 7, Haushman and LM, it showed that the model used is Pool Least Square. With PLS test, it shows that Firm Size and Equity Size have a significant influence on return on equity. Based on PLS testing, firm size variables have a significant influence of less than $1 \%$ and negative influence on return on equity. It indicates that firm size has a significant influence on ROE. ROE is the ratio between net income to total equity. The bigger a company, the greater the dominating ability will be. Therefore, it has the ability in determining the sales price. In banking industry in Indonesia, it is known by the size of Tier I through IV. Also, it is known as too big to fail. The results of this test support the researches done by Petria et al. (2015), Al-Jafari \& Alchami (2014), Lipunga (2014).

In addition to the firm size, return on equity is also affected by equity size. Return on Equity is the ratio of the ratio between net profits to equity. Hence, it can be concluded that equity is an important variable in measuring ROE. The larger the equity size, the smaller the ROE ratio can be. This is in line with dividend and agency theory.

Leverage in the PLS model does not show a significant effect on ROE. It is due to the fact that the profit of the finance company is not solely on the interest expense derived from the loan and other funding sources. The profit of the finance company consists of the income minus the interest expense of the loan and the operating expenses of the company. This study is in line with Pratheepan's (2014) research. 
Table 7. Research Results on Return On Equity

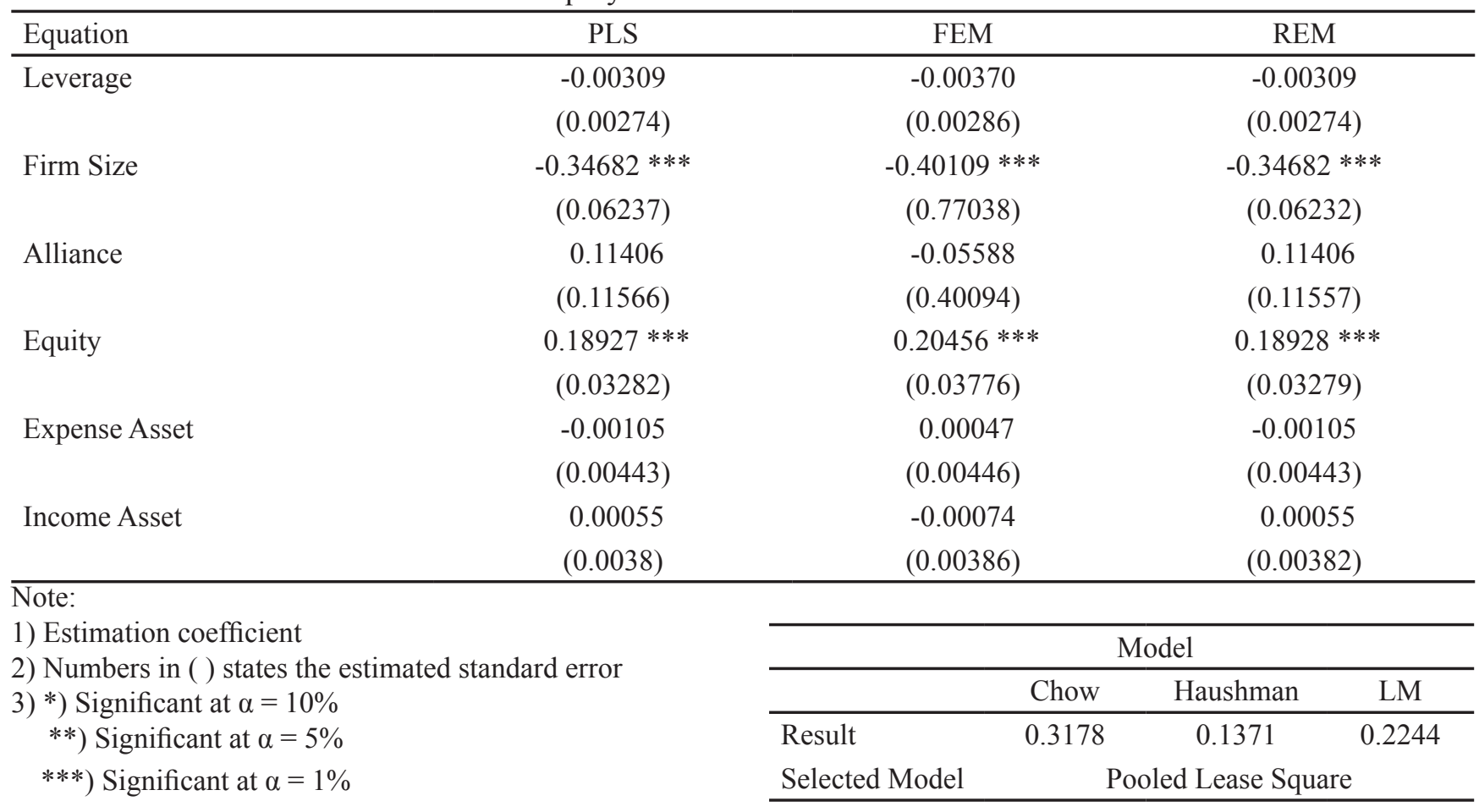

The Alliance also has no influence to the ROE of the finance company. It shows that the profitability of the finance company depends not only on the support of the parent company. This is in line with the sample used in this company where more than $50 \%$ are independent companies.

\section{Managerial Implications}

Based on the research result, the company management should focus on how manage the company efficiently and increase the size of asset of the company. To increase the return on asset, the management of company should manage the profit margin and efficiency ratio. However, to achieve the return on equity, the company should consider the equity size and the firm size.

\section{CONCLUSIONS AND RECOMMENDATIONS}

\section{Conclusions}

Profitability of finance companies is influenced by leverage ratio, efficiency ratio, and firm size. The more efficient the financial companies, the more possible for them to increase their profit. A higher leverage ratio will also increase the profitability of finance companies. The size of company will be in line with the efficiency ratio.
The bigger size, the higher efficiency will be achieved. This research supports the results of researches done by Marnilin \& Darmansyah (2015) and Capraru and Ihnatov (2014).

Return on asset of finance company is influenced by net profit margin and efficiency ratio. The efficiency ratio has an effect on profitability. Profitability compared to total assets is return on asset ratio. Net Profit Margin is the source of income of finance companies, the higher net profit margin, the higher the income of finance companies are. This result is in line with researches done by Dietrich and Wanzenried (2014), and Ahmad (2015).

Return on equity of finance company is influenced by firm size and equity size. The greater the value of equity the smaller the potential of the ROE is. Conversely, if the increase in the value of equity is less than the increase in profitability value, then the return on equity will be higher. Hence, the equity value has an influence on return on equity. Firm Size also has an influence on return on equity. Finance companies have a limit value of the ratio of debt to owned capital. Therefore, the firm size affects the return on equity as shown in Table 8 . The results of this test support the researches done by Petria et al. (2015), Al-Jafari \& Alchami (2014), Lipunga (2014). 
Table 8. Research Summary

\begin{tabular}{ll}
\hline Determinants & Relationship to Profitability \\
\hline Net Profit Margin & Positive \\
Leverage & Positive \\
Efficiency Ratio & Positive \\
Firm Size & Negative / Positive \\
Equity Size & Positive \\
\hline
\end{tabular}

\section{Recommendations}

We propose the management of the finance company should focus on the firm size, equity size and manages the firm efficiently to be able to achieve better profit and return. On the other hand, the finance company should have a better profit margin. The profit margin will be derived from the good portfolio performance and better efficient in managing the business.

\section{REFERENCES}

Ahmad GN. 2015. Determinan profitabilitas bank: studi kasus pada bank pembangunan daerah. Jurnal Keuangan dan Perbankan 19(3): 431-438.

Aissa SB. Goaied M. 2015. Determinants of Tunisian hotel profitability: The role of managerial efficiency, Tourism Management

Al-Jafari MK. Alchami M. 2014. Determinants of bank profitability: evidence from Syria. Journal of Applied Finance \& Banking 4(1): 17-45.

Béjaoui R. Bouzgarrou H. 2014. Determinants of Tunisian Bank. The International Journal of Business and Finance Research 8(4).

Burca A. Batrinca G. 2014. The determinants of financial performance in the Romanian Insurance Market. International Journal of Academic Research in Accounting, Finance and Management Sciences 4(1):299-308.http://dx.doi.org/10.6007/ IJARAFMS/v4-i1/637

Capraru B. Ihnatov I. 2014. Bank's Profitability in Selected Central and Esteran European Countries, 21st International Economic Conference 2014, IECS 2014, 16-17 May 2014, Sibiu, Romania, Procedia Economics and Finance 16 (2014) 587591.

Capraru B. Ihnatov I. 2015. Determinants of Bank's Profitability InEU15, De Gruyter Open, Scientific Annals of the "Alexandru Ioan Cuza" University of Iasi. Economic Sciences 62(1): 93-101.

Cekrezi A. 2015. Determinants of financial performance of the insurance companies: a case of Albania, International Journal of Economics, Commerce and Management III(4).

Chronopoulos DK, Liu H, McMillan FJ, Wilson JOS. 2013. The Dynamics of US Bank Profitability Working Papers in Responsible Banking \& Finance WP No 13-007, 2nd Quarter 2013

Dawood U. 2014. Factors impacting profitability of commercial banks in Pakistan for the period of (2009-2012). International Journal of Scientific and Research Publications 4(3).

Dietrich A, Wanzenried G. 2014. The Determinants of commercial banking profitability in low, middle, and high income countries, The Quarterly Review of Economics and Finance, 54 (2014), 337-354.

Lipunga AM. 2014. Determinants of profitability of listed commercial banks in developing countries: evidence from Malawi. Research Journal of Finance and Accounting 5(6).

Marnilin F, Darmansyah JMVM. 2015. Analisis determinan terhadap persistensi laba pada perusahaan jasa di BEI. Media Riset Akuntansi, Auditing, \& Informasi 15(1).

Maryadi S,. Basuki TA. 2014. Determinan kinerja keuangan bank perkreditan rakyat konvensional. Jurnal Ekonomi dan Studi Pembangunan 15(1):55-63.

Mwangi M. Murigu JW. 2015. The determinants of financial performance in general insurance companies in Kenya. European Scientific Journal 11(1).

Petria N, Capraru B, Ihnatov I. 2015. Determinants of Banks' Profitability: Evidence from EU27 banking system. 7th International Conference on Globalization and Higher Education in Economics and Business Administration, GEBA 2013, Procedia Economics and Finance 20 (2015) 518-524

Pratheepan T. 2014. A Panel data analysis of profitability determinants empirical results from sri lankan manufacturing companies. International Journal of Economics, Commerce and Management II (12).

Samad A. 2015. Determinants bank profitability: empirical evidence from bangladesh commercial banks. International Journal of Financial Research 6(3).

Tan Y,Floros C. 2014. Risk, profitability and competition : evidence from the chinese banking industry. The Journal of Developing Areas 48 (3). 
Tariq W. 2014. Determinants of commercial banks profitability: empirical evidence from Pakistan, International Journal of Accounting and Financial Reporting 4 (2).

Utami T. Kusuma IW. 2017. Detirminan kualitas laba pada isu pengadopsian international financial reporting standard: data dari Asia. Jurnal Akuntansi and Investasi 18(1): 1-12.
Zaid NAM. Ibrahim WMFW. Zulqernain NS. 2014. The determinants of profitability: evidence from Malaysian Construction Companies, Proceedings of 5th Asia-Pacific Business Research Conference 17 - 18 February, 2014, Hotel Istana, Kuala Lumpur, Malaysia, ISBN: 978-1-922069-44-3. 